\title{
A Preliminary Analysis of British New England With Her Mother Country Debates About the Currency Issue
}

\author{
WANG Wei-hong \\ Northeast Normal University, Changchun, China
}

\begin{abstract}
Currency is one of indispensable mechanism for the commercial economy development. As the complexity of the British New England commercial economy growing, the urgent need for a stable value currency as a means of payment of daily trading. But the currency was always a problem restricting the development of commercial economy of New England, which was not only related to the economic management function of colonial government itself, but also a political game between colonies and her mother country government.
\end{abstract}

Keywords: currency, alternative currency, liberty of coinage, bills credit

\section{Introduction}

For any commercial economy development, currency is one of indispensable element or mechanism. In 17th-18th century, with the complexity of the British New England commercial economy was growing stronger day by day, which urgently needs a stable payment means, such as stable value, easy to carry, widely accepted of the precious metal coins or paper money. However, currency (here only refer to coins or paper money) was always a tricky problem for colonial economic develop, it was not only involved economic management function of the colonial government itself, but also a political game between colonies and her mother country government. Besides, the colonial internal and the Atlantic credit system establishment and development provided an important mechanism or way for the colonial trade development. Academic research on this problem, America scholars were involved in some studies, however, they did not put the development of New England monetary and credit development on the political relations change process between British New England and her mother country (Flynn, 2001; Rousseau \& Stroup, 2010, p. 3). For these reasons, this article will explore how British New England solved currency shortage of economic development and analysis the changes of its relations with Britain.

\section{Shortage of Money and Alternative Currency and the Establishment of Credit System}

In most of time of the 17th century, shortage of money was always a major restricted problem for the economic development of British New England. Colonists were trying to increase the money supply in a variety of ways, at the same time, they actively looking for alternatives to maintain and promote the growth of colony internal and overseas trade (Rousseau \& Stroup, 2010, p. 4).

First of all, as a British subsidiary, New England colonial governments did not have any power of issue currency, who only earned money through her home country or other colonial trader. However, due to the trade

WANG Wei-hong, Ph.D. candidate, History and Culture College, Northeast Normal University. 
between New England with England had been in a condition of income could not offset expenditure, so money in the hands of colonists will soon flow back to England. Moreover, most of the time, the British royal government banned exports to colonial coins and bullions (Rousseau \& Stroup, 2010, p. 3). Therefore, inadequate money greatly limited the extension of the colonial trade, and made the transaction cost increases. To compensate for currency flow back to the home country unceasingly, colonists can only earn some money through other trade way. For example, in the case of lack of currency, colonists with West Indians, Iberia and Latin America to port for all kinds of goods trade, which became a prime source of monetary compensation (Margaret Ellen, 1991, p. 126). But the problem is that the trade objects of New England also faced problem of shortage of money, that meaning New England money shortage may not be fundamentally resolved through the trade with her trading partner.

Secondly, colonists temporarily resolved the problem of money shortage through alternative currency or "commodity currencies". In the 1640s, because of economic difficulties, firstly colonial governments accepted in a particular commodity as a means of tax payment, and then more and more people were willing to accept these commodity currencies, such as grain, tobacco, fish and beef, all of that can be used as commodity currencies. But not all things could serve as commodity currencies, there were a lot of a product or service will not be accepted as a means of payment, such as cultivated land service (Flynn, 2001, p. 18). Although these commodity currencies temporarily alleviated payment difficulties within the colonial economy, and had some effect on the stable social order to a certain extent, after all, this kind of commodity currencies were different from the precious metal currency which have very good stability value function, it was just used and circulated within a small scale and the short term, and when it comes to more distant or transoceanic trade, this kind of money obviously were not easy to trade in other parts of the trade partner. Especially such as the British businessmen, they would not willing to accept the diversity of commodity currency besides coins, because it didn't like such as tobacco and indigo have broad market demand in England which could quickly sell into cash (Flynn, 2001, p. 19). So, in this case, the colonists only seek other way to solve the lack of money.

Thirdly, colonists tried to build a colonial "internal credit system", so as to achieve a certain degree of non-cash transactions. Because they did not have enough coins in daily trading, so businessmen, traders and producers took in the form of various non-cash transactions on internal trade. For example, all kinds of products trading were generally by the small shops to coordinate in a small town. They not only provided all kinds of imports of manufactured goods to local residents, but also acquisition the local residents producing or processing all kinds of agricultural products, and for the residents to save transaction records. That is to say, after products of farmers sold to shops, they did not immediately to switch back to the value of the imported goods, but was recorded, so that needs to be taken out at any time. Also, a lot of time, the shop keeper will agree with credit, provided to residents goods first, and then let them with all kinds of agricultural products pay back in the future. As for the two sides in what standard or to each other can accept specific price for these transactions, in most of the time were relying on each other's experience and trust each other, and the price of the government regulation. When trades beyond the scope of a small town, such as in a small town merchants and small traders a little far away was often the barter trade. In addition, some rural small traders need to lend money to others go far away (Rousseau \& Stroup, 2010, p. 4). In the colonies under the situation of currencies were not much, this kind of lending did not necessarily took the form of cash, more was in the form of physical, such as the small town merchants lending to rural traders may be worth 100 pounds of British imports of 
manufactured goods, the last small traders payment was its acquisition of the value of 120 pounds from the country's agricultural products. Also, to maintain both sides continue to trade was still trust each other. The credibility of the relationship between individuals was important to maintain the business relationship.

Finally, "Atlantic credit system" provided a convenient way for the development of colonial trade over a long distance. As Breen said, "Indeed, the entire chain of merchandising from British manufacturers to rural American consumers depended on liberal credit arrangements. Without such a system, the colonists could not have participated in the Atlantic economy. They never possessed an adequate money supply. Specie quickly drained back to the mother country, and though some colonies issued paper currency, these bills did not satisfy the requirements of long distance trade" (Breen, 1986, p. 495). And sustains the credit system was implemented through a variety of personal relationships, especially with kinship, affinity, even religious relations, etc. However, as New England merchants in the Atlantic world trade was expanding, the arrival of more and more strange region, and the uncertainty of population increase, so that relied on direct personal relations obviously difficult to maintain long-term stable business relationships. In this case, the business reputation, good reputation, had become very important in the link of building and maintaining business relationships (MoCusker \& Morgan, 2000, p. 3). New England merchants had a good business reputation in the Atlantic world, which was a reason of their trade successful.

\section{New England Colonists Trying to Obtain the Liberty of Coinage}

Although New England colonists came up with a variety of ways to solve insufficient currency trading inconvenience, they were still desperately hope to have a more stable medium of exchange. Therefore, New England colonial governments first tried to circumvent the home country government regulation, secretly casting money. Then colonial governments repeated requesting to the royal government hoped to get liberty of coinage, but ultimately failed to reach a wish. Finally, the Massachusetts government once accidentally bills issuance, achievement of a paper currency.

During Cromwell's reign (1649-1660), the British government control of the North American colonies was relatively loose. In this period, New England colonies from the home country government intervention at least on its economy and free trade development, New England saw themselves as a state of "freedom commonwealth" (Sainsbury, 1880, p. 15). So that, some of the colonial governments tried to casting coins in order to make up for the constant flow of their own money. In the 1650s, along with the increase of trade with the West Indies and other regions, New England merchants earned a lot of coins, but these coins soon into the European merchant's pockets due to import European manufactured goods. In view of this situation, the Massachusetts government decided to set up their own mint. Make this decision, on the one hand, was based on New England got a lot of Spanish coins, gold and silver pieces and so on through trade with the West Indies, this offered the raw materials for casting coins; On the other hand, many people, especially merchants agreed to colonial government risk to do it (Felt, 1839, p. 30). These new casting coins temporarily provided a more convenient payment medium for internal colonies trading. However, in terms of foreign trade, foreign businessmen gave the very low exchange value to colonial coins, so this made colonial merchants a disadvantage, not much better than use English or Spanish coins was more cost-effective.

By 1660, after the restoration of the Stuart, the royal government strengthened the control of the America colonies. Royal government considered to Massachusetts's coined money was an invasion to the royal 
prerogative and this was traitorous and disloyal, were charged with seeking independence (Henry Bronson, 1865, p. 18). Then told Massachusetts government stop casting currency, "which forbad all foreign coin, except of the mother country, to pass current" (Felt, 1839, p. 41). Moreover, without the permission of the royal government, colonies would not to casting currency. In 1661, John Giffard stated in a letter to sec. Nichholas:

They have acted repugnant to the laws of England; they have allowed the King's coin to be bought and melted down in Boston to be new coined there, by which means they gain three pence in every shilling, and lessen his Majesty's coin a full fourth. (Sainsbury, 1880, p. 26)

Initially Massachusetts government did not obey the orders of the royal government and openly against the royal government in many ways, including continued casting money without authorization (Sainsbury, 1880, p. 75). So the relationships between Massachusetts and mother government became tense, and lots of negative reports were heard continuously by royal government about New England colonies (Sainsbury, 1880, pp. 285, 345-346). And then, Colonists provided to the king all kinds of gifts, including masts, cranberryes, timber, codfish, beaver skins to relieve the wrath of the king, but they couldn't achieve desired effect (Henry Bronson, 1865, p. 19). Lastly, the Massachusetts government was pressured by her home country explained to the royal government about coined money, and promised to correct the wrong behavior. On January 13, 1678, the king forgave the Massachusetts government without the authorization of the king to casting currency. But given the difficulties do exist in the colonies, the king allowed to establish a mint in Massachusetts, with the image of the king of casting gold and silver coins, these coins only internal circulation in the colonies in the future (Sainsbury, 1896, p. 211). Thus it is not hard to see, on the currency issue of this time, the royal government and Massachusetts government all took a compromise. The royal government adopted the policy concessions, temporarily in order to ensure New England colonies loyalty to the royal government and maintained the influence to consolidate of British Empire in North America. Because there was indeed some of threats about New England would sell colonies to the king of Spain (Sainsbury, 1880, p. 75).

Since then, however, there were a lot of Britain's financial officials say to the king, statements casting currency may produce adverse consequences in colonies, claiming cancel the right of free coined in colonies so as to ensure the privileges of the king and the unification of the currency within the British dominion (Felt, 1839, pp. 45-46). Therefore, the charter of the Massachusetts colony was cancelled in 1685, the following year shut down its mint. And then, in the face of ongoing oppositions, some people in the colonies to the British royal government requested the liberty of coinage, especially after the Glorious Revolution, they saw a hope of free coined right. In 1691, Sir William Phips and Increase Mather praying for liberty of coinage, on the following grounds: (1) There are practically only Spanish money in New England, and many of the people have been cheated by bad money; (2) The prosperity of New England depends greatly on trade; there can be no quick trade without money, nor money without liberty of coinage; (3) Liberty of coinage will remove the difficulties of shopkeepers for want of small change; (4) The privilege has been granted to other colonies, the East India Company, etc; and (5) It will satisfy the people that they are not losers but gainers by the new settlement of Government (Fortescue, 1901, p. 568). However, the Massachusetts government failed to get liberty of coinage from the royal government in the end, but required terminating thoroughly existing mint. At this point, liberty of coinage of colonial New England was completely end. But before casting coins were used in various trades for a long time until revolution (Felt, 1839, pp. 48-49). Since then, New Englander only to consider other solutions, such as Banks and issuing bills credit to resolve the difficulties of money shortage. 
And there will be lots of debates on currency issue between New England colonies and her home country government.

\section{The Use of Bills Credit as Paper Currency and Circulation}

To the end of the 17th century, money shortage led to colonial trade a serious recession, as well as the manufacturing and commercial encountered heavy difficulties. And money shortage caused multiple debts, and then the economic and financial litigation case greatly increased. To this end, Massachusetts governor Dudley (1647-1720), argued that unless allowed some medium of exchange issue except coins, which could repair the adverse current economic situation. He had a thought that could let the Bank Bills or Credit it is have personal property and reputation guarantee instead of money to pay. The most important reason for do that was bills and credits could be more convenient and safe than coins. Moreover, other countries or regions have similar practice, which was extremely useful to promote trade and growth in wealth (Felt, 1839, p. 46). And finally made this kind of method to practice soon was a payment difficulties caused by a war. In 1690, Massachusetts government organized a conquest of Canada's failure, because government had no money paid to the soldiers, and forced into practice the ideas mentioned above. At that time, Massachusetts government imprinted 40,000 pounds in bills of credit of 1720s. With these bills paid off the salary of the soldiers, and promised to receive them into the treasury for all public dues at an advance of five percent (Davies, 1738, p. 269). That is to say, this is a delayed payments way under a special case, which belongs to the advance bill in nature. So, the fundamental goal of colonial government to issue these bills was not to issue a transactions medium. However, the fact was these bills in circulation of colonial society, up to the currency function in fact.

In a few short years, Massachusetts bills issued by government from a temporary bills credit became real money and circulation could buy any goods. Thereafter, Massachusetts government opened the floodgates to this practice, and followed by other colonies. And, in the amount of issuance, recovery period and interest were constantly refresh records in all of New England colonies. At the same time, New England to issue bills credit got the support of her home country government. In a short term, it conformed to the fundamental interests of royal government because of issuing bills credit has solved payment difficulties by colonies for expedition, which was conducive to the expansion of the British colonial power in North America. So the king agreed to Massachusetts government to issue bills credit in the new charter (Headlam, 1936, p. 172). Therefore issuance of bills credit to some extent became a dose of good medicine repairing relationship between New England colonies and her home country.

From early 18th century, bills credit gradually became the circulation of money, which had became an important medium of integration of British New England internal economy. In 1702, Massachusetts government withdrew all previously issued bills and then continued to issue new bills credit. In 1709, Connecticut government began to issue bills credit in response to the currency of a serious shortage, and paid off the French expeditionary. In 1710, New Hampshire and in after Rhode Island were issued their own bills credit. Moreover, these four colonies of New England bills were standard each other, and free circulation in the internal of New England, and it became a legal public and private means of payment in 1712 (Rousseau \& Stroup, 2010, p. 4). Thus, each colony bills issue, to a certain extent could relieve daily transaction demand for money, which was beneficial to expand trade in goods within a single colony and between colonies. More importantly, bills were issued and admitted by each other, which would have an effect of strengthening economic ties between the colonies, helped to enhance the degree of economic integration between them. By 
issuing bills, the financial difficulty of colonial governments was temporary relief, and the government had the resources to make better public investment. However, colonial governments could not unlimited issue bills, it must be fully considering the actual tax ability can counter has issued or upcoming bills.

In 1714, Massachusetts government passed a law, decided to issue 50,000 pounds of bills, the interest rate of five percent, the deadline of pay back of principal and interest for five years. In 1716, it passed another law issued 10-year bills at 100,000 pounds. In 1721, anther issued 50,000 pounds. Between 1727 and 1729 issued 68,000 pounds bills. So the colonial government continued to issue bills increasingly as an important way of increasing government spending. Until 1737, the number of bills issued each year had varying degrees of increase. After 1738, until 1740, bills issuance dropped sharply, the total amount of not more than 6000 pounds every year. In 1741 began to increase the number of bills issued (Davies, 1963, pp. 2-3, 30-31). Other colonies, New Hampshire, Connecticut, and Rhode Island were also issued their own bills. In 1733, Rhode Island, on the 20 years, issued a total of 104,000 pounds of bills; Connecticut issued 40,000 pounds. All British New England issued 300,000 pounds bills (Davies, 1938, pp. 269-270).

Like any region's economy, if unlimited issue bills, bound to lead to inflation. When Massachusetts government began to issue bills, fully considering the actual situation of the colonial government fiscal revenues and expenditures, the quantity issuance of bills was limited, and interest and recover deadline were made clear rules (Davies, 1937, p. 30). Because the bill paper money itself does not have any value, so it must be tied directly and the price of gold and silver to value conversion, if excessive circulation or not recover in time the risk of inflation will occur. For example, a new bank was established in Boston in 1733, circulation of bills to reach 110,000 pounds during this period. Its rules, when bills expired, converted into real silver, silver will be 19 shilling per ounce or 13 pounds 13 shilling 1.5 pence in gold price per ounce for conversion (Davies, 1737, p. 31). If the actual number of outstanding bills too much, that could lead to actual the value of gold or silver reduce, namely appear currency devaluation. By the end of 1733, silver from 19 shilling up to 20 shilling per ounce. Soon after, the colonial bills fall further, silver was up to 20 to 27 shilling per ounce (Davies, 1738, pp. 269-270). In 1736, Rhode Island only 530 pounds of bills was equivalent to the 100 pounds of money in Britain (Headlam, 1953, p. 254). The depreciation of paper bills means that goods prices rapidly rising and the conflicts between debtors and creditors had a rise. Especially to the priest and other wage earners caused great difficulties, and for widows and orphans, their property and the interest of this could be able to support them, but the value of its assets down by half, they found themselves suddenly fell into poverty (Hutchinson, 1936, p. 174). So, against voice to the bills appeared from colonies to home country (Margaret Ellen, 1991, pp. 212-215). As early as February 8, 1727, Mr. Popple to Lt. Gov. Dummer said, "Lords Commissioners not thinking it for the good of the Province or the merchants trading there, that these bills of credit should be any longer continued, they expect you will take the necessary care that the bills of 100,000 pounds now circulating in your Government by vertue of the aforesaid Act, may be all called in and destroy'd in May next, as that Act does then expire and that for the future you do not pass any Act for creating a paper currency, without H. M. express leave for that purpose" (Headlam, 1928b, p. 215). But, the Massachusetts colony didn't stop and continued to issue bills. British government was concerned about bills issue in New England colonies more and more, resulting in their relationship of anxious again.

In early 1730, the British government decreed for the New England colonies which prevented prolong the bills' retirement periods, reduce the number of outstanding bills in circulation, and bills issued by the total 
amount shall not exceed 30,000 pounds, and can only be used for government expenses (Margaret Ellen, 1991, p. 218). This order made the leaders of the New England colonies in a dilemma. On the one hand, the colonial leaders couldn't be completely refused to follow Britain's such orders by directly; On the other hand, New England had unavoidable difficulties in daily economic life. On January 28, 1738, Massachusetts governor Jonathan Belcher to Council of Trade and Plantations stated the reasons of issue bills. Because "this province labours under great difficulties for want of something to pass in lieu of money, silver and gold being as constantly exported to Great Britain as it comes in; and it is hardly possible for the people to subsist or any trade to be carried on without a medium of exchange or something to pass between man and man". Actually, Many more opposition unlimited issue bills, think that should back the old after issue new. On March 30, 1739, the Massachusetts traders reported to the Council of Trade and Plantations that did not agree Massachusetts legislation about issued 60,000 pounds bills (Davies, 1994, pp. 71-72). On April 11, 1739, the Council of Trade and Plantations submitted above comments to the king. At last the king agreed to Massachusetts government issued new bills to meet the following conditions: (1) Before the issuance of new bills, bills issued before 1727 need to be recall and scrape; (2) Issued after 1727, now still in circulation, are not entirely out of circulation, can't issue more than a year to pay the value of new bills; (3) The value of new bills as six shillings eight pence; (4) New bills will be back on a regular in three, six, 10 years; and (5) Formulate appropriate provisions to protect lenders losses caused by bankruptcy (Davies, 1739, p. 77).

Therefore, Colonies to issue bills strictly limited by the mother country government, who tried to standardize the order of the colonial economy, to stop bills depreciation, and protected the interests of British businessmen of the colonial trade. But, when in October of 1739, Britain and Spain began to colonial wars, and wars Britain and France started again in 1744, the British government needed the help of the New England colonies, and in order to solve the war spending, New England colonial government in addition to the issuance of bills, which the British government introduced acquiescence (Henry Bronson, 1865, pp. 46, 63). Especially in 1744-1748, each colony of New England issued a lot of bills. However, once the end of wars, some of the British businessman petitioned parliament again immediately stop colonial bills circulation (Margaret Ellen, 1991, pp. 238, 239, 240). So, to a large extent, New England colonies could issue bills, issuing how much depended on the interests of the British, and despite amount of bills would cause serious consequences. For example, Bills increasingly serious depreciation, from 28 shilling convertible 1 ounces of silver in 1739 rose to 32 shillings in 1744, even up to 55 or 60 shilling in 1749 (Henry Bronson, 1965, p. 70). Paper currencies depreciation caused many colonial families sink into poverty.

Although by issuing bills, largely promoted the development of colonial economy and provided a more convenient medium of exchange for the colonial trade. However, New England colonies bills issued must be conformed to the interests of her home country. As the home country government pressure was aggravating, Massachusetts government announced all bills stop circulation after March of 1750, restored use coins to pay (Felt, 1839, p. 121). In 1751, the British parliament made a law that asked all of New England colonies no governor and deputy governor and legislature shall make issue bills again from September 29 of 1751 (Henry Bronson, 1865, p. 70). Therefore, New England colonies returned to money shortage era like the end of last century. Until the late 1760s, colonial traders generally complained about lack of money among them, can't pay for Britain to New England for most of the export goods (Cluny, 1770, p. 62). Therefore, some of the British businessman also claimed that allows New England merchants pay all of manufactured goods in the form of 
other. As a British businessman said, "If we should insist on having our returns in money, it might destroy our trade". ${ }^{1}$ So, New England paid off with tobacco or sugar, etc. to England as much as times.

\section{Conclusions}

In short, New England had faced a serious shortage of money in 17th-18th century, which seriously restricted the development of colonial commercial economy. Therefore, New England colonial governments took various channels to solve the currency shortage. Especially colonial government tried to solve the problem of insufficient medium of exchange by issued coins, but British government considered this kind of behavior was a challenge to the authority of the government. As a result, the currency issue became a factor affected the relationship between New England colonies and her mother country. The currency intervention to New England colonies was a performance of British to increase control of colonial America. This kind of intervention and control evoked colonists dislike and even against her mother country, affected the healthy development of the relationship between the colonies and her mother country. Liberty of coinage or bills credit issue became a common right by the colonists increasingly asking, and when the right did not implement, it seems to have not far from colonies to independent.

\section{References}

Breen, T. H. (October, 1986). An empire of goods: The anglicization of Colonial America, 1690-1776. Journal of British Studies, 25(4), 467-499.

Cluny, A. (1770). The American traveller: Or observations on the present state, culture and commerce of British Colonies in America. In A Series of Letters. By an old and experienced trader. London: E. and C. Dilly and J. Almon.

Davies, K. G. (Ed.). (1963). Calendar of State Papers, Colonial Series, America and West Indies, Volume 43, 1737. British History Online. London. Received from http://www.british-history.ac.uk/cal-state-papers/colonial/america-west-indies/vol43

Davies, K. G. (Ed.). (1969). Calendar of State Papers, Colonial Series, America and West Indies, Volume 44, 1738. London. British History Online. Retrieved from http://www.british-history.ac.uk/cal-state-papers/colonial/america-west-indies/vol44

Davies, K. G. (Ed.). (1994). Calendar of State Papers, Colonial Series, America and West Indies, Volume 45, 1739. London. British History Online. Retrieved from http://www.british-history.ac.uk/cal-state-papers/colonial/america-west-indies/vol45

Felt, J. B. (1839). An historical account of Massachusetts Currency. Boston: Perkins \& Marvin.

Flynn, D. T. (2001). Credit and the economy of Colonial New England (Ph. D. diss.). Indiana University.

Fortescue, H. J. W. (Ed.). (1901). Calendar of State Papers, Colonial Series, America and West Indies, Volume 13, 1689-1692. London. British History Online. $\quad$ Retrieved from http://www.british-history.ac.uk/cal-state-papers/colonial/america-west-indies/vol13

Headlam, C. (Ed.). (1928). Calendar of State Papers, Colonial Series, America and West Indies, Volume 28, 1714-1715. London. British History Online. Retrieved from http://www.british-history.ac.uk/cal-state-papers/colonial/america-west-indies/vol28

Headlam, C. (Ed.). (1936). Calendar of State Papers Colonial, America and West Indies, Volume 35, 1726-1727. British History Online. Retrieved from http://www.british-history.ac.uk/cal-state-papers/colonial/america-west-indies/vol35

Headlam, C. (Ed.). (1953). Calendar of State Papers, Colonial Series, America and West Indies, Volume 42, 1735-1736. London. British History Online. Retrieved from http://www.british-history.ac.uk/cal-state-papers/colonial/america-west-indies/vol42

Henry Bronson, M. D. (1865). A historical account of connecticut currency, continental money, and the finances of the revolution. New Haven: Thomas J. Stafford, Printer.

Hutchinson, T. (1936). The history of the Colony and Province of Massachusetts-Bay, Vol. II. Cambridge, Massachusetts: Harvard University Press.

Margaret Ellen. (1991). Newell, economic ideology, culture and development in New England, 1620-1880 (Ph. D. diss.). University of Virginia.

MoCusker, J. J., \& Morgan, K. (Eds.). (2000). The early modern Atlantic economy. New York: Cambridge University Press.

\footnotetext{
${ }^{1}$ Early American Imprints Series I, no. 3290: “The Interest of City and Country to Lay no Duties”, New York, 1726, pp. 9-10.
} 
Rousseau, P. L., \& Stroup, C. (July 2010). Monetization and growth in New England, 1703-1749. National Bureau of Economic Research Working Paper No. 16190. Retrieved from http: //www.nber.org/papers/w16190

Sainsbury, W. N. (Ed.) (1880). Calendar of State Papers, Colonial Series, America and West Indies, Volume 5, $1661-1668$. British History Online. Retrieved from http://www.british-history.ac.uk/cal-state-papers/colonial/america-west-indies/vol5 Sainsbury, W. N. (Ed.) (1896). Calendar of State Papers, Colonial Series, America and West Indies, Volume 10, 1677-1680. British History

Online.

Retrieved

from

http://www.british-history.ac.uk/cal-state-papers/colonial/america-west-indies/vol10 